\title{
Beaconites antarcticus in the (?Middle) Late Devonian McAras Brook Formation, Cape George, Nova Scotia
}

$$
\begin{aligned}
& \text { P.M. Bruck*, W.H. Forbes*, D. Nance** and R.K. Pickerill **** } \\
& \text { *University College, Cork, Ireland } \\
& \text { *University of Maine at Presque Isle, Maine } 04769 \\
& \text { *University of Ohio, Athens, Ohio 45701 } \\
& \text { ***University of New Brunswick, Fredericton, N.B. E3A 5A3 }
\end{aligned}
$$

\begin{abstract}
Beaconites antarcticus has recently been recorded in (?Middle-) Late Devonian fluvial siltstones of the McAras Brook Formation, Nova Scotia. Although previously noted in several North American Palaeozoic sequences the trace fossil has not, until now, been documented from Nova Scotia. Herein we note its occurrence and compare it to previously reported examples which occur in similar stratigraphical and
\end{abstract} environmental settings particularly from the British Isles and Antarctica.

On rapporte la présence de Beaconites antarcticus dans des siltstones fluviaux de la Formation de McAras Brook, du Dévonien tardif (?moyen) de la Nouvelle-Ecose. Bien que déjà connue dans plusieurs séries du Paléozoique de l'Amérique du Nord, on n'avait auparavant jamais documenté cette trace en Nouvelle-Ecosse. Nous notons donc ici son occurrence et la comparons aux nombreux exemples déjà recensés dans des cadres stratigraphiques et environnementaux similaires, plus particulièrement au Royaume-Uni et en Antarctique.

\section{INTRODUCTION}

The Ballantynes Cove section of the (?Middle-) Late Devonian McAras Brook Formation at Cape George, Nova Scotia, has recently yielded several specimens of the trace fossil Beaconites antarcticus which occur in association with ?eurypterid tracks. Although Beaconites has recently been noted and illustrated from both the United States (Bridge and Gordon 1985, Bridge and Drowser 1985) and Arctic Canada (Narbonne 1984) it has never been reported from Nova Scotia. Besides that of Narbonne (1984) the only other Canadian occurrence known to us is from the Devonian Perry Formation of southern New Brunswick (see Nilsen 1982, fig. 46A, p. 27) though this example was unnamed. Despite the paucity of North American recordings the trace fossil has been extensively reported from both British (e.g. Allen 1978, 1979; Bridge et al. 1980, Allen and Williams 1981) and Antarctic (e.g. Gevers et al. 1971, Bradshaw 1981) sequences. In this short paper we note the occurrence of Beaconites, emphasize its depositional environment within the sequences and compare it to previously documented recordings.

\section{GEOLOGIC SETTING}

The Devonian and Carboniferous redbeds of Cape George, Nova Scotia, MARITIME SEDIMENTS AND ATLANTIC GEOLOGY $21,87-96$ (1985)
[Traduit par le journal] occupy a fault-bound peninsula that forms the prominent northeastern corner of mainland Nova Scotia (Fig. 1). The regional geology, as described by Boucot et al. (1974), comprises a core of Browns Mountain Group metasediments and metavolcanics that have since been reassigned to the Hadrynian Georgeville Group (Murphy et al. 1982). These are unconformably overlain to the north by coarsegrained conglomerates and basalt flows of the McAras Brook Formation. To the east, Late Devonian (Benson 1970) conglomerates of the Horton Group (sensu lato in the designation of Keppie et al. 1978) and unconformably overlying redbeds and limestones of the Early Carboniferous (Tournaisian; Keppie et al. 1978) Wilkie Brook Formation are downfaulted along the Browns Mountain Fault (Fig. 1). Cape George itself comprises a thick succession of conglomerates that tectonically overlie the McAras Brook Formation along a thrust zone that extends from Livingstone Cove to Ballantynes Cove (Fig. 1), and have been variously assigned to both the Horton Group (Boucot et al. 1974) and an unnamed unit of possible Devonian age (Keppie 1979). This fault and similar structures on the northern tip of Cape George point to significant, southwarddirected Variscan thrusting and have been interpreted as reflecting the termination of right lateral slip on the Hollow Fault to the west (Nance 1980). 


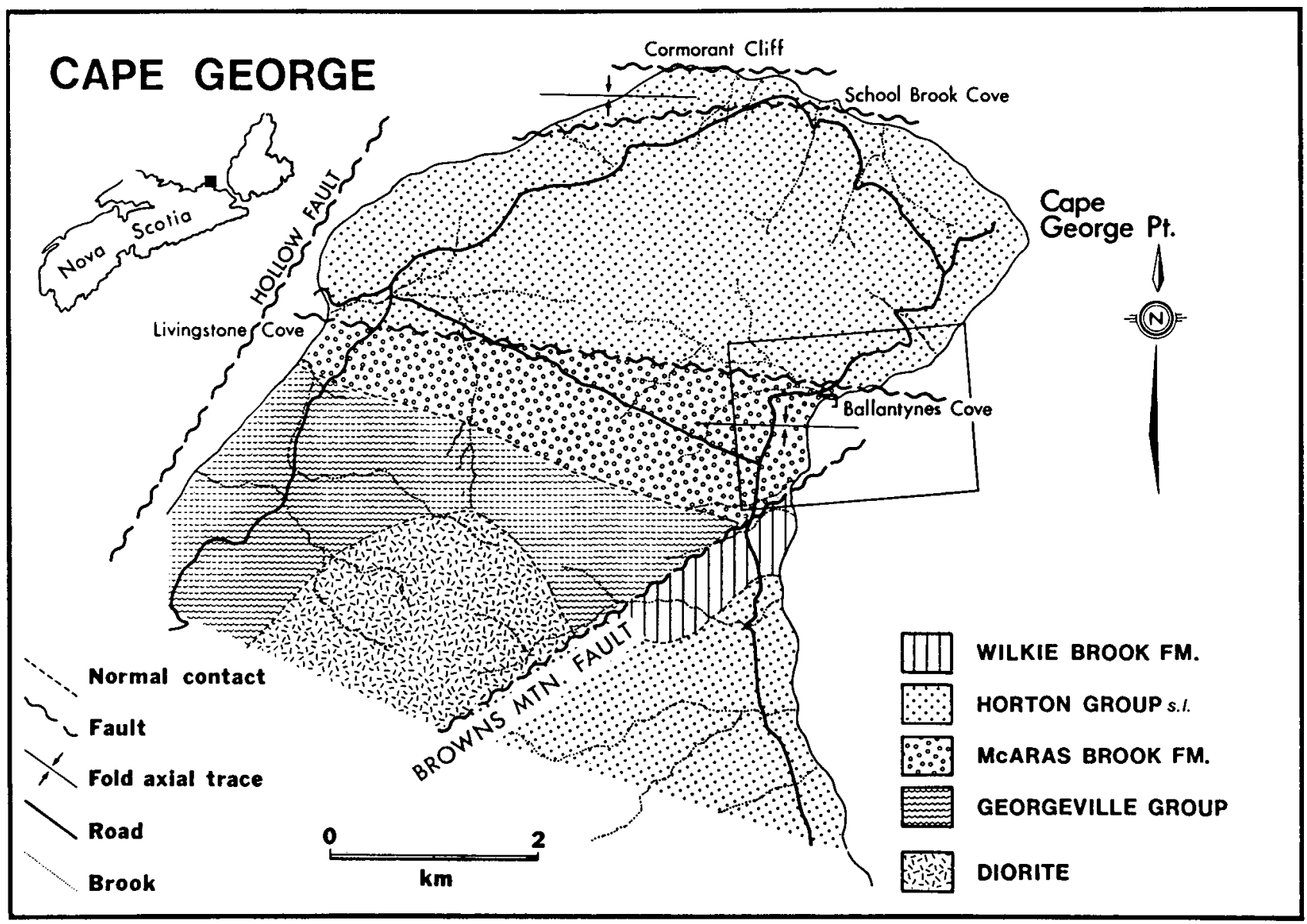

Fig. 1 - Simplified geological map of the Cape George peninsula, Nova Scotia (after Boucot et al. 1974).

Relationships are well-exposed at Ballantynes Cove (Fig. 2), where the thrust zone is marked by a deformed, strongly polymict conglomerate unit of unknown affinites that separates overturned beds of the McAras Brook Formation from undeformed conglomerates and sandstones of the tectonically overlying Horton Group (sensu lato). Beneath the thrust zone the McAras Brook succession is repeated above a major east-west, overturned syncline that developed in response to the emplacement of the Horton Group (sensu lato) from the north (Nance 1980). The occurrence of B. artarcticus immediately south of the synclinal axis (Fig. 2) consequently places it close to the top of the exposed McAras Brook succession on the fold's normal limb.

\section{MCARAS BROOK FORMATION AT BALLANTYNES COVE}

\section{Stratigraphic succession}

The broad stratigraphy of the McAras Brook Formation, as exposed in both fold limbs, and its probable correiation across the fold axis are schematically illustrated in Figure 3. Basal portions of both successions comprise a number of dark green, amygdaloidal basalt flows interbedded with massively bedded conglomerates. Individual flows, at least seven of which are recognized on the southern limb, show conglomeratic tops in which weathered, highly amygdaloidal basalt cobbles lie in a matrix of red sandstone. Pebbles within the interbedded conglomerates are largely siltstones and sandstones presumably derived from the nearby Georgeville Group and are characteristically hematite-coated. The base of the formation is not exposed, but at Livingstone Cove, (Fig. 1) a similar basaltic unit is underlain by a further $60 \mathrm{~m}$ of massive conglomerates that rest with 
slight angular unconformity on meta-siltstones of the Georgeville Group. Central portions of the succession are dominated by massive, proximal fanglomerates of ca. $150 \mathrm{~m}$ in thickness in which subrounded to subangular cobbles are again derived principally from presumed Georgeville Group siltstones and sandstones. Upper portions of this unit, exposed only on the southern limb (Fig. 3), become increasingly finer grained and are interbedded with red, cross-stratified and linguoid rippled sandstones, and purple siltstones showing desiccation cracks, rain imprints and numerous trace fossils, including ?eurypterid tracks and, as described herein, B. antarcticus (Fig. 4). These are conformably overlain by ca. $20 \mathrm{~m}$ of grey and green, thin-bedded siltstones and limy shales that contain abundant plant debris. Grey shales at or close to the horizon bearing B. antarcticus contain palynormorphs identified by M.S. Barss as probably Late Devonian and possibly partly Middle Devonian in age (Keppie et al. 1978). However, the precise relative stratigraphic positions of the two localities is uncertain as the succession is left laterally offset at this location by a minor strike-slip fault that parallels the cliff-base (Fig. 1). The upper contact of the formation is not exposed.

Keppie et al. (1978) divided the succession on the southern limb of the overturned syncline at Ballantynes Cove into two formations of approximately equal thickness - namely, a lower unit comprising the volcanics and conglomerates described above and an upper conglomerate and siltstone unit. These authors termed the lower unit the McAras Brook Formation and equated it with that seen at the type section at McAras Brook, some 30 miles southwest of Cape George. The upper sedimentary unit was classed by these authors as a 'Formation - not named'.

Our studies of the Ballantynes Cove section and the McAras Brook type section, however, show that there seems to be no sound reason for separating the sediments from the volcanics at Ballantynes Cove as a separate formation. Very similar sediments are interbedded with volcanics at the type section, where they are grouped with the McAras Brook Formation. At Ballantynes Cove, therefore, we include the entire volcanic and overlying sedimentary sequence into the McAras Brook Formation. However, for the type section we agree with Keppie et al. (1978) that the upper part, approximately, of the McAras Brook Formation as defined by Williams (1914) and Bell (1926) should be classified as a separate formation (the Martin Road Formation of Keppie et al. 1978); this upper unit comprises mainly buff sandstones and shale-pebble conglomerates that contrast with the red sandstone pebble conglomerates and basalts of the McAras Brook Formation.

\section{Occurrence of Beaconites antarcticus}

We have noted $B$. antarcticus at two levels in the McAras Brook Formation at Ballantynes Cove, within the southern synclinal limb. The highest level occurs on the eastern side of the minor strikeslip fault referred to above, apparently $8 \mathrm{~m}$ stratigraphically below the top of the highest conglomerate unit. At this locality a red, thinly bedded, sandy and silty $70 \mathrm{~cm}$ thick unit is present with conspicuous desiccation cracks, rain imprints, and trace fossils including ?eurypterid tracks. The upper surface expressions of several B. antarcticus burrows are seen here (Fig. 4) and range in size from ca. $6 \mathrm{~cm} \times 5 \mathrm{~cm}$ to $\mathrm{ca} .1 \mathrm{~cm} \times 0.5 \mathrm{~cm}$; all show tectonic elongation in the same direction. The unlined and faintly meniscate burrows occur on the top surface of the $70 \mathrm{~cm}$ thick siltstone unit, the overlying beds being eroded away at this locality. The burrows are revealed by a fill of darker red fine-grained sandstones within paler red surrounding siltstone. Downward extensions of the burrows are not exposed but in other respects the 2dimensional expression strongly resembles B. antarcticus as described elsewhere (see later).

B. antarcticus is also present lower in the sequence further south along the shore at Ballantynes Cove. This locality (Fig. 2) is within a $3 \mathrm{~m}$ thick unit of thin red coloured parallel bedded fine-grained 


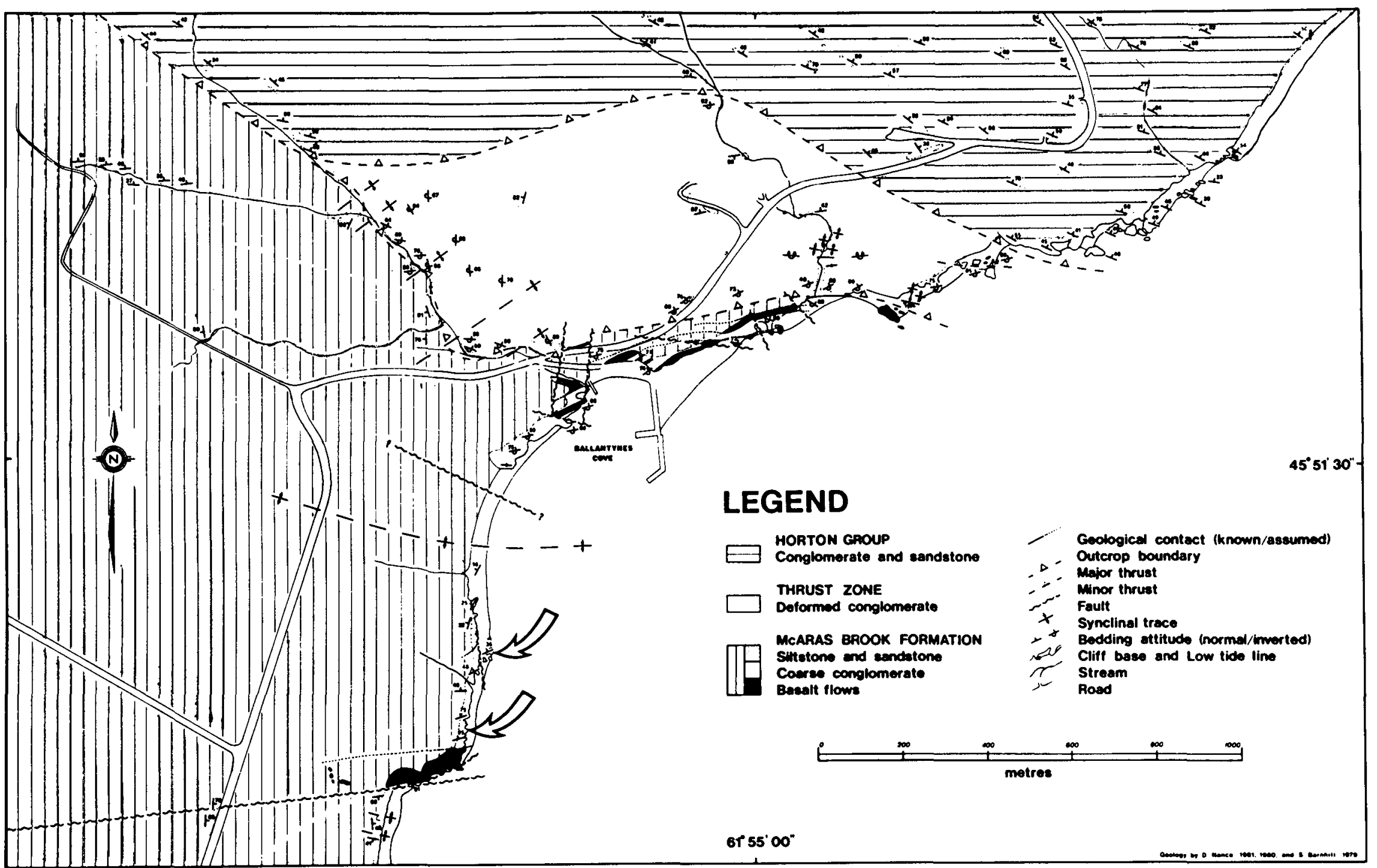

Fig. 2 - Geologic outcrop map of the Ballantynes Cove area (see Figure 1 for location) indicating the two locations (arrowed) at which B. antarcticus was observed. 
conglomerates, sandstones, siltstones and mudstones overlying the lowest conglomerate unit of the formation. Beds range in thickness from $10 \mathrm{~cm}$ to $20 \mathrm{~cm}$ and $\mathbf{B}$. antarcticus occurs $80 \mathrm{~cm}$ above the base of the unit at the top of a red siltstone and beneath a red mudstone. Plan views of two B. antarcticus burrows are seen (Fig. 5). One burrow is filled with darker red sandstone within paler red siltstone; the other shows no colour differences with respect to the siltstone but has a $1-2 \mathrm{~mm}$ high raised rim. Both burrows are roughly circular in plan and about $1 \mathrm{~cm}$ in diameter. Other unnamed trace fossils are associated with both burrows.

We have also investigated sediments of the McAras Brook Formation throughout its type section along the shore eastwards from McAras Brook. Abundant trace fossils were noted, and are currently under more detailed investigation, but no B. antarcticus burrows were obvserved.
Sedimentary environment

This initially coarsening and ultimately fining-upward sequence reflects the development and demise of a subaerial alluvial fan system initiated in response to local fault movements heralded by basaltic volcanism, and closed through loss of topographic relief. Such tectonic control of sedimentation is typical of many post-Acadian successor basins in the northern Appalachians (Blanchard et al. 1984), including the type McAras Brook Formation near Arisaig to the southwest, where basaltic volcanism and fanglomeratic sedimentation signals initial basin rifting (Fralick and Schenk 1981). Finer grained, B. antarcticus-bearing portions of the Ballantynes Cove succession are more typical of associated fluviatile lithologies, in particular overbank deposits. The presence of ?eurypterid tracks would suggest that conditions were transitional to lacustrine or perhaps a brackish water environment.

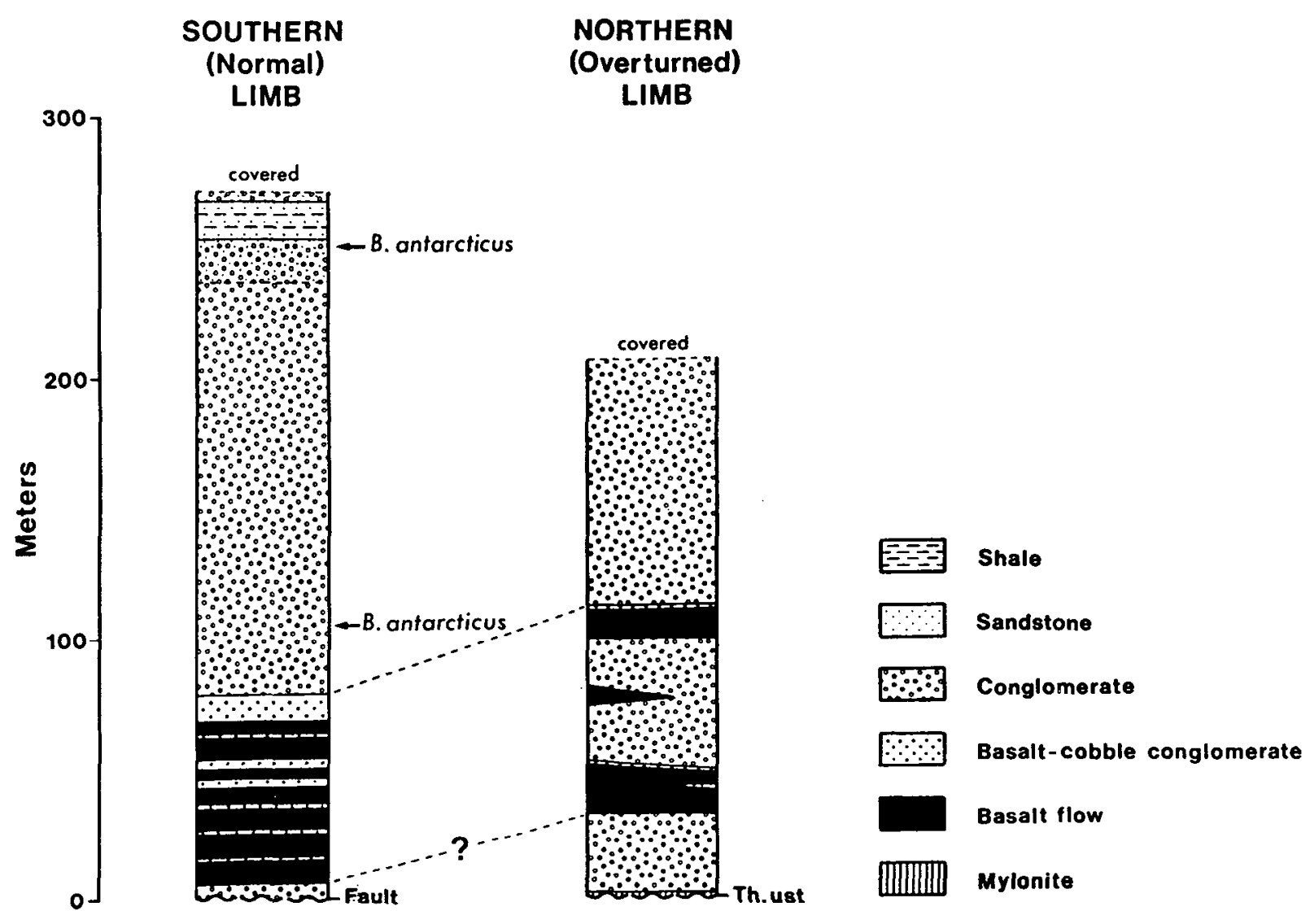

Fig. 3 - Schematic stratigraphic sections for the McAras Brook Formation at Ballantynes Cove. 
Brück et al.
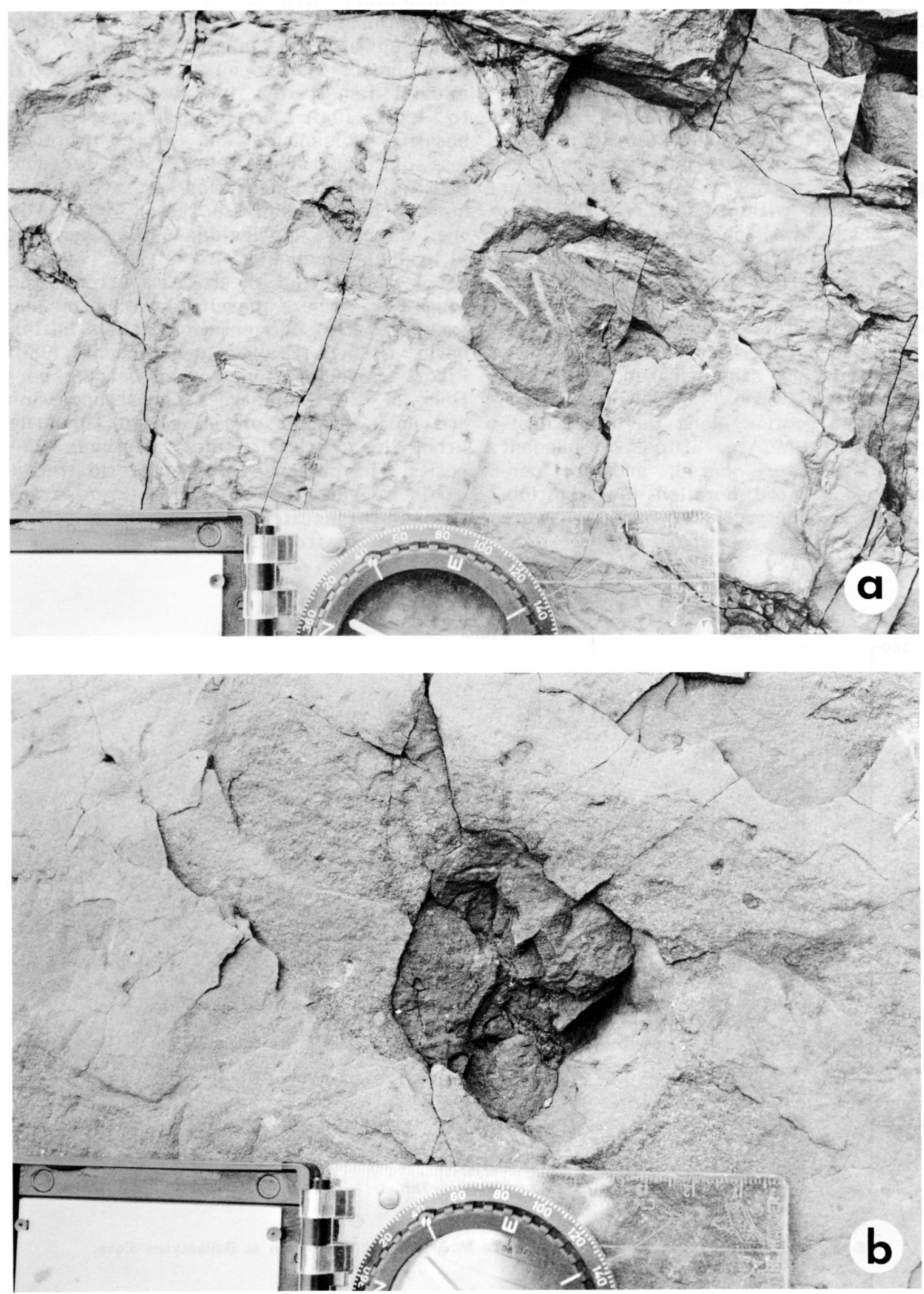


\section{DISCUSSION}

As noted by Frey et al. (1984) and Squires and Advocate (1984), there is still considerable taxonomic confusion in the naming of both lined meniscate burrows (e.g. Ancorichnus) and unlined meniscate burrows (e.g. Beaconites, Laminites, Taenidium, Scalarituba, Muensteria, etc.). Until a thorough taxonomic re-evaluation of these varied ichnogenera is completed all are still regarded as valid. It must be noted, however, that the discussion below refers specifically to examples or records where Beaconites has been specifically identified as such. Other, particularly non-marine, examples of morphologically similar burrows of similar dimensions have been referred to by other authors as Taenidium or, more commonly, Muensteria (for example see Bracken and Picard 1984). Until taxonomic revision has been undertaken, it is not worthwhile to include such recordings in our discussion.

Although the full 3-dimensional aspect of the Nova Scotia burrows described herein is unknown, comparison with previously described and often equally incomplete examples leaves little doubt that they can be confidently assigned to Beaconites. At present, Beaconites is represented by two ichnospecies, namely $B$. antarcticus Vialov, 1962 and B. barretti Bradshaw, 1981. The essential differences between these two ichnospecies and their detailed diagnoses have been summarized by Bradshaw (1981) who noted that $B$. barretti was wider, more sinuous and possesses a narrower internal sediment packing that shows greater curvature. Based on these characteristics we therefore assign the Nova Scotia examples to B. antarcticus.

As summarized by Graham and Pollard (1982), a wide variety of potential producing organisms have been thought responsible for the construction of Beaconites burrows. Such organisms range from worms, burrowing lungfish, arthropods to even reptiles (Graham and Pollard 1982).
The incomplete preservation of the Nova Scotia examples does not, however, lend support to any of the proposed producers and, indeed, more than a single group of organisms may have been responsible.

To date, Beaconites has been recorded in strata ranging in age from the Silurian (Narbonne 1984) to the Permian (Graham and Pollard 1982) and possibly Triassic (see Seilocher 1963). As previously noted, North American occurrences are poorly documented, but do include those by Bridge and Gordon (1985) and Bridge and Droser (1985) from Devonian strata of the Catskill Delta and by Narbonne (1984) from the Silurian (Ludlow) or Arctic Canada. The only other North American recording known to us is that by Nilsen (1982) who figures but does not name the burrow in the Upper Devonian Perry Formation of southern New Brunswick. Clearly, however, this burrow can be confidently assigned to Beaconites. The examples described herein are therefore the first from Nova Scotia. In contrast to North America, the trace has been extensively documented from both Antartica (Vialov 1962, Haskell et al. 1965, Webby 1968, Gevers et al. 1971, Bradshaw 1981) and the British Isles (e.g. Ridgeway 1974, 1976; Pollard 1976; Forsyth and Chisholm 1972; Allen 1978, 1979; Allen and Williams 1981; Graham and Pollard 1982). Notably, all these examples occur in Devonian or Carboniferous strata, all of which are interpreted as non-marine in origin. Like the examples described herein, it appears obvious that the producer(s) of Beaconites preferred terrestrial conditions. Although there may be problems with respect to taxonomic considerations, it is, however, nevertheless clear that the Beaconites-producing organism(s) were not necessarily everywhere restricted to non-marine environments. Narbonne (1982) and Bridge and Droser (1985), for example, have reported it from marginal marine environments. As supported by the Antarctic, the British Isles and the examples described herein, however, it

Fig. 4 (opposite page) - Beaconites antarcticus in bedding plane expression (upper surface) in the McAras Brook Formation at Ballantynes Cove.

a. One large and two small B. antarcticus burrows at higher level in McAras Brook Formation.

b. Large B. antarcticus burrow at higher level in McAras Brook Formation. 

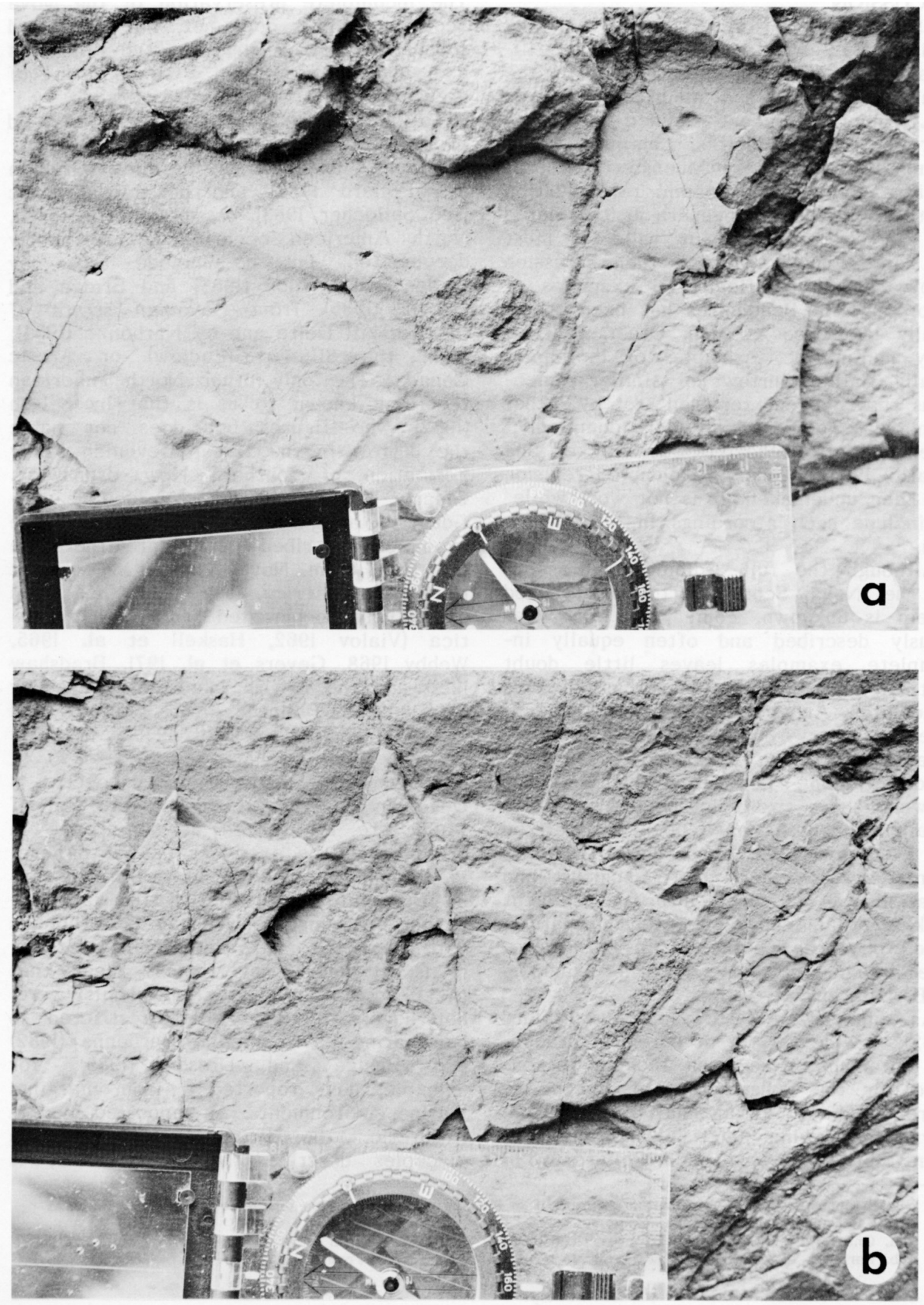
remains equally true that the 'preferred' environmental regime of the Beaconitesproducing organism(s) was decidedly nonmarine, particularly, as noted by Graham and Pollard (1982), characteristic of fluvial sediments of floodplain, overbank or active channel origin.

\section{ACKNOWLEDGEMENTS}

We are most grateful to H.C. Teng and Brendan Murphy (St. Francis Xavier University) and Michael O'Sullivan (University College, Cork) for helpful discussions in the field and laboratory. Critical reviews of the initial version of the manuscript were provided by L.R. Fyffe and D. Fillion and for their varied and useful comments we are grateful.

ALLEN, J.R.L. 1978. Locality Bl5 - Gelliswick Bay, Dyfed. In $A$ field guide to selected outcrop areas of the Devonian of Scotland, the Welsh Borderland and South Wales. Edited by P.F. Friend and B.P.J. Williams. Palaeontological Association, pp. 87-88.

ALLEN, J.R.L. 1979. The Old Red Sandstone Facies in external basins with particular reference to southern Britain. Special Papers in Palaeontology, 23, pp. 65-80.

ALLEN, J.R.L. and WILLIAMS, B.P.J. 1981. Beaconites antarcticus: a giant channel-associated trace fossil from the Lower Old Red Sandstone of South Wales and the Welsh Borders. Geological Journal, I6, pp. 255-269.

BELL, W.A. 1926. Carboniferous formations of Northumberland Strait, Nova Scotia: Geological Survey of Canada, Summary Report, 1924, Part C, pp. 142-180.

BENSON, D.G. 1970. Notes to accompany geological maps of Antigonish and Cape George map areas, Nova Scotia. Geological Survey of Canada, Paper 70-8, 2p.

BLANCHARD, M.C., JAMIESON, R.A. and MORE, E.B. 1984. Late Devonian - Early Carboniferous volcanism in western Cape Breton Island, Nova Scotia. Canadian Journal of Earth Sciences, 2l, pp. 762-774.

BOUCOT, A.J., DEWEY, J.F., DINELEY, D.L., FLETCHER, R., FYSON, W.K., GRIFFIN, J.G., HICKOX, C.F., MCKERROW, W.Z. and ZIEGLER, A.M. 1974. Geology of the Arisaig area, Antigonish County, Nova Scotia. Geological Society of America, Special Paper 139, 191p.

BRACKEN, B. and PICARD, M.D. 1984. Trace fossils from Cretaceous/Tertiary North Horn Formation in central Utah. Journal of Paleontology, 58, pp. 477-487.
BRADSHAW, M.A. 1981. Paleoenvironmental interpretations and systematics of Devonian trace fossils from the Taylor Group (lower Beacon Supergroup), Antarctica. New Zealand Journal of Geology and Geophysics, 24, pp. 615-652.

BRIDGE, J.S. and DROSER, M.L. 1985. Unusual marginal-marine lithofacies from the Upper Devonian Catskill clastic wedge. In The Catskill Delta. Edited by D.L. Woodrow and W.D. Sevon. Geological Society of America, Special Paper 201, pp. 143-161.

BRIDGE, J.S. and GORDON, E.Z. 1985. Quantitative interpretation of ancient river systems in the Oneonta Formation, Catskill Magnefacies. In The Catskill Delta. Edited by D.L. Woodrow and W.D. Sevon. Geological Society of America, Special Paper 201, pp. 163-181.

BRIDGE, J.S., VEEN, P.M. VAN and MATTEN, L.C. 1980. Aspects of the sedimentology, palynology and palaeobotany of the Upper Devonian of southern Kerry Head, Co. Kerry, Ireland. Geological Journal, 15, pp. 143-170.

FORSYTH, I.H. and CHISHOLM, J.I. 1977. The Geology of East Fife. Memories of the Geological Survey of Scotland, Edinburgh, 284p.

FREY, R.W., PEMBERTON, S.G. and FAGERSTROM, J.A. 1984. Morphological, ethological and environmental significance of the ichnogenera Scoyenia and Ancorichnus. Journal of Paleontology, 58, pp. 511-528.

FRALICK, P.W. and SCHENK, P.E. 1981. Molasse deposition and basin evolution in a wrench tectonic setting: the late Paleozoic, eastern Cumberland basins, Maritime Canada. In Sedimentation and tectonics in alluvial basins. Edited by A.D. Miall. Geological Association of Canada, Special Paper 23, pp. 77-97.

GEVERS, T.W., FRAKES, L.A., EDWARDS, L.N. and MARZOLF, J.E. 1971. Trace fossils in the Lower Beacon sediments (Devonian) Darwin Mountains, southern Victoria Land, Antactica. Journal of Paleontology, 45, pp. 81-94.

GRAHAM, J.R. and POLLARD, J.E. 1982, Occurrences of the trace fossil Beaconites antarcticus in the Lower Carboniferous fluviatile rocks of County Mayo, Ireland. Palaeogeography, Palaeoclimatogy, Palaeoecology, 38, pp. 257-268.

HASKELL, T.C., KENNETT, J.P. and PREBBLE, W.M. 1965. Geology of the Brown Hills and Darwin Mountains, southern Victoria Land, Antarctica. Transactions of the Royal Society of New Zealand, 2, pp. 231-248.

KEPPIE, J.D. 1979. Geological map of the Province of Nova Scotia. Nova Scotia Department of Mines and Energy, scale 1:500,000.

KEPPIE, J.D., GILES, P.S. and BOEHNER, R.C. 1978. Some Middle Devonian to Lower Carboniferous rocks of Cape George, Nova Scotia. Nova Scotia Department of Mines and Energy, Paper 78-4, 36p.

MURPHY, J.B., KEPPIE, J.D. and HYNES, S.J.

Fig. 5 (opposite page) - Beaconites antarcticus in bedding plane expression (upper surface) in the McAras Brook Formation at Ballantynes Cove.

a. Smaller B. antarcticus burrow at lower level in McAras Brook Formation.

b. B, antarcticus burrow with raised rim at lower level in McAras Brook Formation. 
1982. Geologic Map of the northern Antigonish Highlands. Nova Scotia Department of Mines and Energy, Map 82-3.

NANCE, D. 1980. Structural interpretation of Cape George, N.E. Nova Scotia. Geological Association of Canada/Mineralogical Association of Canada, Program with Abstracts, 5, p. 73.

NARBONNE, G.M. 1984. Trace fossils in Upper Silurian tidal flat to basin slope carbonates of Artic Canada. Journal of Paleontology, 58, pp. 398-415.

NILSEN, T.M. 1982. Alluvial Fan Deposits. In Sandstone Depositional Environments. Edited by P.A. Scholle and D. Spearing. American Association of Petroleum Geologists, pp. 49-86.

POLLARD, J.E. 1976. A problematical trace fossil from the Tor Bay Breccias of South Devon. Proceedings of the Geological Association, 87, pp. 105-108.

RIDGEWAY, J.M. 1974. A problematical trace fossil from the New Red Sandstone of South Devon. Proceedings of the Geological Association, 85, pp. 5l1-517.
RIDGEWAY, J.M. 1976. Reply to discussion. Proceedings of the Geological Association, 87, pp. 108-109.

SEILACHER, A. 1963. Lebensspuren und salinitatsfazies. Fortschritte in der Geologie von Rheinlend und Westfalen, 10, pp. 81-94.

SQUIRES, R.L. and ADVOCATE, D.M. 1984. Meniscote burrows from Miocene lacustrine-fluvial deposits, Diligencia Formation, Orocopia Mountains, southern California. Journal of Paleontology, 58, pp. 593-597.

VIALOV, O.S. 1962. Problematica of the Beacon Sandstone at Beacon Height West, Antarctica. New Zealand Journal of Geology and Geophysics, 5, pp. 718-732.

WEBBY, B.D. 1968. Devonian trace fossils from the Beacon Group of Antarctica. New Zealand Journal of Geology and Geophysics, 1l, pp. 1001-1006.

WILLIAMS, M.Y. 1914. Arisaig-Antigonish District, Nova Scotia. Geological Survey of Canada, Memoir 60, 173p.

REVIEWERS: L.R. Fyffe 